\title{
Effect of Organic and Mineral Nitrogen Fertilization and Some Growth Stimulants on Productivity of Strawberry for Exportation
}

\author{
Badr' $^{1}$, L.A., M. H. Mohamed ${ }^{1}$, A. E. Shehata ${ }^{2}$ and Y.A. Gad-Allah ${ }^{2}$ \\ ${ }^{1}$ Horticulture Dept., Fac. Of Agric., Benha university \\ ${ }^{2}$ Hort. Res. Institute, Agriculture Research Center, Egypt.
}

\begin{abstract}
Two field experiments were carried out during the two successive seasons of 2017/2018 and 2018/2019 in Elkanater Horticulture Research Station, Kalubiya Governorate, to investigate the effect of organic or mineral nitrogen fertilization levels with soil addition of humic acid, EM and TS as well as the foliar spray with some growth stimulants (Phosphrin, Micoind an Orset-x) on vegetative growth, chemical composition, fruit yield and its quality of strawberry plants (Fragaria X ananassa Duch) cv. Fortuna. This experiments included 16 treatments resulted from the combinations of four Nitrogen fertilizer treatments and four spray treatments as follows, $50 \%$ compost- $\mathrm{N}+50 \%$ mineral- $\mathrm{N}$ fertilizers $+\mathrm{EM}, 50 \%$ compost $-\mathrm{N}+50 \%$ mineral- $\mathrm{N}$ fertilizers $+\mathrm{TS}, 50 \%$ compost $-\mathrm{N}+50 \%$ mineral- $\mathrm{N}$ fertilizers + humic acid and $100 \%$ mineral $\mathrm{N}$ fertilizer at a rate of $200 \mathrm{~kg} \mathrm{~N} / \mathrm{fed}$ as recommended dose. Meanwhile, foliar spray treatments, Phosphrin at 5ml/1, Micoind at 2g/l, Orset-X at $1 \mathrm{~g} / \mathrm{l}$ and control (sprayed only with tap water). Obtained results showed that, the application of the recommended dose of nitrogen fertilizer (200kg N/fed) in form of $50 \%$ compost $+50 \%$ mineral $\mathrm{N}+\mathrm{TS}$ combined with foliar spray with Phosphrin at $5 \mathrm{ml} / 1$ gave the highest vegetative growth parameters, chemical constituents of plant foliage, fruit yield and its components (early, exportable, marketable and total yield per plant and per fed) and best physical and chemical fruit quality.
\end{abstract}

Key words: Strawberry - mineral - organic- nitrogen fertilizer- growth stimulantus

\section{Introduction}

Strawberry (Fragaria X anannasa Duch.) is one of the most important vegetable crops grown in Egypt for fresh consumption, processing and exportation. It's the unique vegetable crop belong to family Rosaceae. The average area devoted to grow strawberry in Egypt was increased and reached about 32379 fed which 29418 fed for fresh production with an average yield of 19.6t/fed and 4960fed for frigo production with an average yield of $12.9 \mathrm{t} / \mathrm{fed}$. Moreover, the total exportable fruit yield was 39 thousand ton according to the statistics of Ministry of Agriculture in 20172018 seasons. The growth, production and quality of produced strawberry fruit are depending on the different agricultural treatments done during the growing season. Nowadays belong to the fertilization with macronutrients many farmers used growth stimulants either as a soil addition or foliar spray on plant foliage to improve growth, productivity and yield quality of produced fruits. Fruit yields of strawberry cultivars depend on soil fertility and water availability during growing season. Therefore, to obtain uniform high yield of good quality fruits it is essential to provide adequate nutrients for proper plant nourishment (Sharma, 2002). Therefore, there has recently been increased interest in the environmentally friendly, sustainable and organic agricultural practices in the world (Esitken et al.,2006). Nowadays, organic products are being famous for all people around the world. Due to the great global market demand, production of organic foods has rapidly increased in the past decades. On this basis organic agriculture has become a great choice as means of organic product producing.
Organic cultured strawberries produced higher vegetative growth in compare to conventionally cultured strawberries produced Abu-Zahra and Tahboub (2008). Different studies indicated that application of compost manure to strawberry field play an important role as soil amendment, improving plant nutrition and enhancing plant growth (Hargreaves et al., 2009). Intensive farming practices that result in high yield and quality also require extensive use of chemical fertilizers, which are costly and create environmental problems. Therefore, there has been a recent, growing interest in various biofertilizers (microbe inoculants). Biofertilizers play a very important role in improving soil fertility by fixing atmospheric nitrogen, both in association with plant roots and without it, solubilize insoluble soil phosphates and produce plant growth substances in the soil. They are in fact being promoted to harvest the naturally available biological system of nutrient mobilization (Venkatashwarlu, 2008). EM is an abbreviation for Effective microorganisms and refers to a cocktail of beneficial microorganisms that is used as a soil amendment. Many growers in Egypt have become interested EM technology as a means of restoring soil productivity. There is increasing evidence that EM can increase the microbial balance, diversity of agricultural soils, plus improving soil and yield quality (Javaid and Shah 2010).

Humic acid (HA) is an effective agent which used as a complement to mineral or organic fertilizers. Soil application of $\mathrm{HA}$; led to improve some physicochemical soil properties such as aggregation, aeration, permeability and water-holding capacity as well as nutrient ion transport, and availability through the $\mathrm{pH}$ buffering (Tan 2003). Humic acid (HA) has 
hormone-like activity which not only enhances the plant growth and the nutrient uptake but also shows an anti-stress effect under abiotic stress conditions such as unfavorable temperature, salinity, and $\mathrm{pH}$ by ameliorating the negative effect of any stress (EIHefny, 2010).

Seaweed extract that is a new generation of natural organic fertilizers is highly nutritious, promotes faster germination of seeds and increases yield and resistant ability of many crops (Dhargalkar and Pereira, 2005). The chemical constituents of seaweed extract include complex polysaccharide, fatty acids, vitamins, phytohormones. Applications of seaweed extract, as a foliar spray, brought an increase in total soluble solids (TSS) and vitamin C of two strawberry cultivars (Masny et al. 2004).

phosphorus (P) element, which is an essential and important nutrient for crop propagation, health and vigor (Li et al., 2010), strawberry plants show an intensification in the tonality of the leaves to a dark green under deficiency. This occurs due to the reduction in the leaf blade area and, consequently, higher concentration of chlorophyll per unit of area Ahire and Gaikwad (2018).

Plant growth regulators used to alter the growth of a plant or plant part. Basically, naphthalene acetic acid (NAA), growth regulators application has been practiced to increase production and quality of fruit crops. Oraset it has been investigated extensively in strawberry. They regulate the plant growth and increase the yield of strawberry Kumar et al., (2012)
The objective of this study was to determine the effect of different rate of organic, inorganic fertilizers, biofertilizer EM (Effective microorganisms), Biofertile, without biofertilizer, TS is amixed from different microorgansmis strains and different foliar applications of oraset, pospholein and mexodain and their interactions on the vegetative growth, chemical contents, fruit yield and chemical quality of strawberry cv. Fertona.

\section{Materials and Methods}

Two field experiments were carried out during the two successive seasons of 2017/2018 and 2019/2020 in El-kanater Horticulture Research Station, Kalubiya Governorate, to investigate the effect of organic or mineral nitrogen fertilization levels with soil addition of humic acid, EM and TS as well as the foliar spray with some growth stimulants (Phosphrin, Micoind an Orset-x) on vegetative growth, chemical composition, fruit yield and its quality of strawberry plants (Fragaria X ananassa Duch) cv. Fortuna. The fresh transplants of the used cultivar were obtained from private nursery. Transplants were dipped in Rhizolex solution at rate of $3.0 \mathrm{~g} /$ liter for 20 minutes as recommended by Ministry of Agriculture for pathogens disinfection before transplanting. The soil of the experimental field was clay loam in texture with pH 7.94 Soil mechanical and chemical analyses are shown in Table (a).

Table A. Soil mechanical and chemical analyses of the used soil

\begin{tabular}{|c|c|c|c|c|c|}
\hline \multirow{2}{*}{\multicolumn{2}{|c|}{ Physical analysis }} & \multicolumn{4}{|c|}{ Chemical analysis } \\
\hline & & \multicolumn{2}{|c|}{ Cations meq/l } & \multicolumn{2}{|c|}{ Anions meq/l } \\
\hline Coarse sand & $1.1 \%$ & $\mathrm{Ca}^{++}$ & 3.36 & $\mathrm{CO}_{3}^{--}$ & Zero \\
\hline Fine sand & $18.20 \%$ & $\mathrm{Mg}^{++}$ & 1.65 & $\mathrm{HCO}_{3}^{-}$ & 4.15 \\
\hline Silt & $25.78 \%$ & $\mathrm{Na}^{+}$ & 3.91 & $\mathrm{Cl}^{-}$ & 3.82 \\
\hline Clay & $54.20 \%$ & $\mathrm{~K}^{+}$ & 0.84 & $\mathrm{SO}_{4}^{--}$ & 1.79 \\
\hline \multicolumn{6}{|c|}{ Texture class clay loam } \\
\hline Soil pH & 7.94 & Available N & 22.5 & & \\
\hline E.C, dS/m & 1.07 & Available $\mathrm{P}$ & $9.1 \mathrm{~m}$ & & \\
\hline Organic matter & $1.21 \%$ & Available $\mathrm{K}$ & $64 \mathrm{~m}$ & & \\
\hline
\end{tabular}

The area of the experimental plot was $10.20 \mathrm{~m}^{2}$ included one bed each six meters in long and 1.70 meters in width. Each bed included four rows and the transplanting was done at $25 \mathrm{~cm}$ apart between transplants in the same row. Transplanting was done on $25^{\text {th }}$ of September in both seasons. Sprinkler irrigation was used in the first month after transplanting, after that the beds were covered with 40 micron black plastic mulch then the drip irrigation was used after mulching until the end of the growing season. This experiments included 16 treatments resulted from the combinations of four Nitrogen fertilizer treatments and four spray treatments as follows.

\section{a. Nitrogen fertilizer treatments:}

1. $50 \%$ compost- $\mathrm{N}+50 \%$ mineral- $\mathrm{N}$ fertilizers +EM

2. $50 \%$ compost $-\mathrm{N}+50 \%$ mineral- $\mathrm{N}$ fertilizers +TS

3. $50 \%$ compost $-\mathrm{N}+50 \%$ mineral- $\mathrm{N}$ fertilizers + humic acid

$4.100 \%$ mineral $\mathrm{N}$ fertilizer in the form of ammonium nitrate $\left[\left(\mathrm{NH}_{4} \mathrm{NO}_{3}, 33.5 \%\right]\right.$ was used. Nitrogen sources were used at a rate of $200 \mathrm{~kg} \mathrm{~N} / \mathrm{fed}$ as recommended by Ministry of Agriculture.

\section{b. Foliar spray treatments:}

Three foliar spray treatments in addition to the control treatment were tested as indicated below.

1. Control (sprayed only with tap water). 
2. Phosphrin at $5 \mathrm{ml} / 1$

3. Micoind at $2 \mathrm{~g} / \mathrm{l}$

4. Orset-X at $1 \mathrm{~g} / 1$

The amounts of organic nitrogen fertilizer (compost) was added at soil preparation, The other quantities of inorganic-N fertilizer (the mineral fertilizer) were added during the growing season. The chemical analysis of the used compost in first and second seasons is shown in Table (2).

Table b. Analysis of compost in the two season.

\begin{tabular}{lll}
\hline Items & First season & Second season \\
\hline $\mathrm{N} \%$ & 1.21 & 1.18 \\
\hline $\mathrm{P} \%$ & 0.63 & 0.67 \\
\hline $\mathrm{K} \%$ & 1.45 & 1.48 \\
\hline $\mathrm{C}: \mathrm{N}$ ratio & $18: 1$ & $17: 1$ \\
\hline Organic matter & 31.68 & 34.58 \\
\hline $\mathrm{PH}$ & 6.71 & 6.86 \\
\hline $\mathrm{EC}(\mathrm{ds} / \mathrm{m})$ & 3.67 & 3.79 \\
\hline $1 \mathrm{~m}^{3}=$ & $412 \mathrm{~kg}$ & $425 \mathrm{~kg}$ \\
\hline
\end{tabular}

The spray treatments were started after 30days from transplanting and every 15 days intervals (from November to the end of Marh).

TS: - is commercial product from Biotech for fertilizers an biocides contain Bacillus circulance, Trichoderma spp, Bacillus polymyxa, Bailus

Effective microorganisms: - (EM as commercial name) was obtained from Ministry of Agriculture and Land Reclamation . the Effective Microorganisms (EM) preparation contains photosynthetic bacteria (Rhodopseudomonas palustrus and Rhodobacter space), milk bacteria (Lactobacillus casei, Streptococcus lactis), yeast (Saccharomyces albus and Candida utilis), actinomycetes (Streptomyces albus and Streptomyces griseus) and moulds (Aspergillus oryzae and Mucom hiemalis) (Javaid and Shah 2010).

Humic Total: - $80 \%$ soluble potassium humate. It is commercial product by Elahlia Agriculture Development Co. It includes: humic acid $80 \%$ and $\mathrm{K}_{2} \mathrm{O} \quad 11-13 \%$

Orset-x:-is commercial product from Union for Agriculture Development (UAD) contain $1.5 \%$ NAA, $0.45 \%$ novaxi acetic acid

Phosphrin: - It is commercial product by Egypt Kona Co. Ltd. It includes: $60 \% \mathrm{P}_{2} \mathrm{O}_{5}$

Micoind:. It is commercial product by Simadac Agrochemistry Co. Ltd. it is including: seaweed extract

The spray treatments were started after 30 days from transplanting and every 15 days intervals for ten times through the growing season. Asplit plot design with four replicates was used in this experiment where the nitrogen fertilizers treatments were distributed in the main plots while the spray treatments were located randomly in the sub plots. The agricultural practices concerning cultivation, fertilization, irrigation and pest- and disease control were conducted as commonly followed according to the recommendation of the ministry of Agriculture for the commercial production of fresh strawberry. Data on vegetative growth, yield and its components, and physical and chemical fruits characteristics were recorded as follows:

\section{Data recorded:}

\section{Vegetative growth characteristics.}

Three plants were taken from each experimental plot as a representative sample on February after130 days from transplanting and the following data were recorded, plant length $(\mathrm{cm})$, number of crowns/plant, number of leaves/plant, fresh weight per plant $(\mathrm{g})$ and dry weight per plant $(\mathrm{g})$

\section{Chemical composition of plant foliage:}

Total Nitrogen, Phosphorus, Potassium and carbohydrates\%, were determined according to Pregl (1945), John (1970), Brown and Lillel and (1946) and Herbert (1971), respectively.

\section{Fruit yield and its components:}

1-Early fruit yield ( $t / f e d)$ : It was determined as weight of all harvested fruits at the ripe stage during November, December and January.

.2. Total fruit yield (t/fed): It was calculated using plot yield and plot area.

3. Fruit yield (g/ plant): It was calculated form fruit yield/plot and number of plants/plot.

4. Exportable yield ( $t / f e d)$ : it was calculated as weight of harvested fruits at the ripe stage during November, December and January after discarding the misshaped fruits.

5- Marketable yield (t/fed): it was calculates after discarding the infected fruit.

6-Unmaretable yield (kg/fed): It was calculated as weight of infected fruit during the harvesting season.

4.1. Physical quality: A random sample of 10 fruits at full ripe stage from each experimental plot was taken to determine the following properties. average fruit weight, length, diameter and fruit 
firmness: It was determined by using Chatillon Penetrometer (N.4., USA) GauGe -R with a needle 3 $\mathrm{mm}$ in diameter. (Qurecky and Bourne,1968).

4.2. Chemical quality:

Total soluble solids (T.S.S.): A random sample of 10 fruits were taken to determine the percentage of soluble solid content by using the hand refractometer, total titratable acidity (T.T.A), ascorbic acid "Vitamin $C$ and anthocyanin content: according to the method described in A. O. A.C. (1990). While, total sugars: were determined colormetrically by the method described by Nelson (1974).

\subsection{Statistical analysis:}

All collected data were subjected to statistical analysis according to Sndecor and Cochran (1991) where the least significant difference was considered when even possible.

\section{Results and Discussion}

\section{1- Vegetative growth traits}

With regard to the effect of the soil addition treatments for the recommended dose of nitrogen fertilizer ( $200 \mathrm{~kg} \mathrm{~N} / \mathrm{fed})$ in the form of $50 \%$ mineral $\mathrm{N}+50 \%$ compost and some bio-fertilizers (TS, EM and humic acid) on vegetative growth characteristics of strawberry plants, data recorded in Table (1) reveal that there were significant difference in all measured morphological growth traits among all taste soil addition treatments compared with the control treatment $(100 \%$ mineral $\mathrm{N}$ fertilizer) during both seasons of growth. In this respect, addition of the recommended dose of nitrogen fertilizer $(200 \mathrm{~kg}$ $\mathrm{N} /$ fed) in the form of $50 \%$ compost $+50 \%$ mineral $\mathrm{N}$ $+\mathrm{TS}$ exhibited the highest values for all tested vegetative growth traits compared with no other tested fertilization treatments and control during both seasons of growth except leaf area per plant in the second one, followed by the treatment of $50 \%$ compost $+50 \%$ mineral $\mathrm{N}+$ humic acid. On the other hand, the lowest values were recorded in case of the control treatment (100\% mineral N). Such results are true during both seasons of growth. such improving effect for compost fertilizer in combination with mineral fertilizer on vegetative growth of strawberry plants may be attributed to the main role of organic and bio-fertilizer as slow release source of macro and micro-nutrients for plant which necessary for cell formation and photosynthetic product assimilation which in turn may affect plant growth, organic fertilizer play an important role in improving soil physical properties and reducing $\mathrm{PH}$ value which affect availability of soil nutrients for up taking by plant and consequently increased plant growth. Cooks(1972) suggested that application of organic and mineral $\mathrm{N}$ fertilizers together may increase the exchangeable water soluble of NPK and the uptake of these elements. Also, the increase in plant growth parameters were connected with the increase in photosynthetic pigments and determined macronutrient content (Table 4) and inturn increased plant growth. Obtained results are in same direction with those reported by Hassan (2015), Reinaldo et al., (2015), Nazik et al. (2017) and Shubash et al., (2018)

Concerning the effect of foliar spray treatments with Phosphrin, Micoind and Orset-x on vegetative growth traits of strawberry plants, the same data at Table (1) show clearly that all studied growth traits, i.e., plant height, numbers of leaves and crowns per plant, crown diameter, fresh and dry weight per plant as well as leaf area per plant were positively affected due to all tested foliar spray treatments compared with the control treatment. In this regard, all tested foliar spray treatments led to a significant increase in all the measured vegetative growth traits of strawberry plants in comparison with the control treatment. In this regard, the highest values for all recorded vegetative growth characteristics of plant were obtained as a result of foliar spraying with Phosphrin, followed by Orset- $\mathrm{x}$ and Micoind ten times beginning after one month from transplanting and every 15 days by intervals. Obtained results are true during both season of growth. The increase in vegetative growth due to the application of tested stimulants may by attributed to the role of such materials as antioxidants which contract the free radical $(\mathrm{O} 2)$ which affect the activity and viability of plant cells. Also it affect on physiological process of plants as well as its roles as promote plant growth. Furthermore, increasing the duration of plant and retard the senescence of plant. In addition, the superiority of Phosphrin may be due to the role of phosphorus as which affect plant cells division and elongation and in turn increased plant growth. Obtained results are in accordance with those reported by Spinelli et al. (2010), Alkharpotly et al.(2017), Husain et al. (2017), Ahire and Gaikwad (2018) and Scott et al. (2018)

With the regard to the effect of the interaction treatments between tested soil addition and foliar spray treatments on the vegetative growth traits of strawberry plant, data in Table (1) reveal that significant differences were found in all studied growth characteristics among all the studied interaction treatments between soil addition and foliar spray during both the growing seasons of study. Moreover, the highest values in such growth aspects were obtained due to the application of the recommended dose of nitrogen fertilizer $(200 \mathrm{~kg} \mathrm{~N} / \mathrm{fed})$ in form of $50 \%$ compost $+50 \%$ mineral $\mathrm{N}+\mathrm{TS}$ combined with Phosphrin, followed by the interaction treatment between the same soil addition treatment Orset-x or Micoind, $50 \%$ compost $+50 \%$ mineral N +humic acid with Phosphrin and the same soil addition with foliar spray by Orset- $x$, obtained results are true during both seasons of study.

\section{2-chemical composition of plant foliage}


As for the effect of the soil addition of nitrogen fertilizer at the recommended dose $(200 \mathrm{~kg} \mathrm{~N} / \mathrm{fed})$ in the form of $50 \%$ compost $+50 \%$ mineral nitrogen with some bio-fertilizers as well as humic acids data in Table (2) indicate that estimated macro elements, i.e. total nitrogen, phosphorus and potassium as well as total carbohydrates were significant differ among the tested soil addition treatments compared with the control treatments $(100 \%$ mineral $\mathrm{N})$ during both growing season. In this respect, the highest values in all determined chemical constituents of plant foliage were obtained in case of adding 50\% compost $+50 \%$ mineral nitrogen $+\mathrm{TS}$, followed by humic acid and EM. On the other hand, the lowest values were obtained from soil addition treatments of the control (100\% mineral nitrogen). The same trend was true in the two seasons of study. The higher mineral and carbohydrates content in case of soil addition of $50 \%$ compost $+50 \%$ mineral nitrogen $+\mathrm{TS}$ was connected with the higher vegetative growth (Table 1). Moreover, the increase in macro- nutrients (PK) may be attributed to the effect of organic fertilizer on reducing the $\mathrm{PH}$ value of the soil, increase the soil microbial biomass and humate which affect on the decomposition and availability of such nutrients which inturn increase its uptake by plant roots. Also, addition of mineral nitrogen fertilizer increase its concentration in soil solution and in turn increased the uptake by plant. In this regard, Hsieh and hsu(1994)reported that the manure increase soil organic matter and the availability of $\mathrm{P}$ and the exchange of $\mathrm{Mg}, \mathrm{Mn}$ and $\mathrm{Zn}$ which inturne affect leaves pigments Obtained results are in accordance with those reported by Hassan (2015), Reinaldo et al., (2015), Nazik et al. (2017) and Shubash et al., (2018)

With regard to the effect of foliar spray with Phosphrin, Micoind and Orset-x, the same data at Table (2) show clearly that foliar spray treatments significantly increased the total nitrogen, phosphorus, potassium and carbohydrates content of the strawberry plant foliage compared with the chick treatments. In this regard, the highest values of all determined chemical composition of plant foliage was obtained as a result of foliar spray with Phosphrin, ten times starting after one month from transplanting an every 15 days by interval during the growing season followed by Orset-x and Micoind. On the contrary, the lowest values were obtained from the control treatments (foliar spray with tap water). Such results are true during the two seasons of study. Obtained results may be due to the synergistic effect of Phosphrin or Orset-x in increasing the absorption of such elements by plant roots. obtained results are agreement with those report by Spinelli et al. (2010), Alkharpotly et al.(2017), Husain et al. (2017), Ahire and Gaikwad (2018) and Scott et al. (2018)

Referring to the effect of the interaction treatments between soil addition and foliar spray with some compounds, data in Table (2) show that the total nitrogen, phosphorus, potassium and carbohydrates concentrations in plant foliage were significantly affected due to the interaction between soil addition and foliar spray treatments. In this respect, the highest values of all estimated chemical constituents of plant foliage was noticed in case of soil addition with 50\% compost $+50 \%$ mineral nitrogen $+\mathrm{TS}$ and foliar spray with Phosphrin, followed by the same soil addition treatment with foliar spray by Orset-x, Micoind and the interaction treatment between soil addition with $50 \%$ compost $+50 \%$ mineral nitrogen + humic acid and foliar spray with Phosphrin. Such results are true during both seasons of study.

\section{3- Fruit yield and its components}

Data recorded in Table (3) show that there were significant differences among tested soil addition treatments with nitrogen fertilizer at the recommended dose $(200 \mathrm{~kg} \mathrm{~N} / \mathrm{fed})$ in the form of $50 \%$ compost + $50 \%$ mineral nitrogen with some bio-fertilizers as well as humic acids in all measured yield and its components parameters in both seasons of growth. In this regard, soil addition treatments $50 \%$ compost + $50 \%$ mineral nitrogen $+\mathrm{TS}$ reflected the highest values in all afore mentioned fruit yield traits compared with the other soil addition treatments except unmarketable fruit yield where the highest value was obtained from the control treatment $(100 \%$ mineral nitrogen), followed by the soil addition treatment $50 \%$ compost $+50 \%$ mineral nitrogen + humic acid. On the other hand, the control treatment (100\% mineral nitrogen) gave the lowest values for aforementioned fruit yield and its components traits except unmarketable fruit yield. Such results are true during both seasons of study. Obtained results were connected with the effect of such treatments on the vegetative growth of plants (Table 1) and chemical composition of plant foliage (Table 2) which reflected on the productivity of plants. The increase in early yield when the organic fertilizer was only applied may be due to the slow release of $\mathrm{N}$ which reduced plant uptake of $\mathrm{N}$ than needed. Accordingly the plant increased the early yield in the expense of total and marketable yield. The highest total yield and marketable yield in case of fertilization using half of recommended dose of nitrogen as compost and other half as mineral nitrogen may be attributed to the balanced uptake of $\mathrm{N}$ which resulted in the highest produced yield per plant or per feddan and marketable yield beside the reasonable percentage of infected fruit (Table, 5).Cooke(1972) indicated that organic fertilizer encourage the plant to have good root development and mineral- $\mathrm{N}$ fertilizers helps the living organisms in organic matter to multiply. Obtained results are parallel with those reported by Hassan (2015), Reinaldo et al., (2015), Nazik et al. (2017) and Shubash et al., (2018)

Concerning the effect of foliar spray treatments with Phosphrin, Micoind and Orset-x on total fruit yield and its components, the same data in Table (3) 
show that foliar spray treatments significantly affected total fruit yield and its components expressed as early fruit yield, exportable fruit yield, plant fruit yield, total fruit yield, marketable and unmarketable fruit yield compared with the control treatment (foliar spray with distilled water). Obtained results were true during both seasons of growth. In this regard, foliar spray with Orset-x reflected the highest early of fruit yield per fedden and exportable fruit yield per fedden , whereas foliar spray with Phosphrin gave the highest values for plant fruit yield, total fruit yield, marketable and unmarketable fruit yield, followed by Orset-x and Micoind. On the other hand, the control treatment (foliar spray with distilled water) gave the lowest values for all measured fruit yield and its components traits except unmarketable fruit yield which gave the highest value. Such results are true during both seasons of study. Such increments in fruit yield (early, marketable, exportable and total yield) due to treating the plants with tested growth stimulant products were connected with their effect on increasing the vegetative growth parameters (Table, 1). In addition, its effects on increasing photosynthetic pigments and macro-nutrients (Table,2) which affect plant growth and inturn increased its productivity. Also using such tested growth stimulants reduced the infected fruit percentage and number of days elapsed to flower anthesis and consequently increased the early and marketable produced yield. Obtained results are in parallel to that reported by Spinelli et al. (2010), Alkharpotly et al.(2017), Husain et al. (2017), Ahire and Gaikwad (2018) and Scott et al. (2018)

Data recorded in Table (3) show clearly that there were significant differences in total fruit yield and its components, i.e., early fruit yield, exportable fruit yield, plant fruit yield, total fruit yield, marketable and unmarketable fruit yield due to the interaction between soil addition and foliar spray treatments. In this respect, the highest early fruit yield and exportable fruit yield were obtained as a result of using the interaction treatment between soil addition of $50 \%$ compost $+50 \%$ mineral nitrogen + TS with foliar spray by Orset-x, followed by Phosphrin. Moreover, the highest values of plant fruit yield, total fruit yield per fedden and marketable fruit yield per fedden were obtained from the interaction between soil addition with $50 \%$ compost $+50 \%$ mineral nitrogen + TS and foliar spray by Phosphrin, followed by the same soil addition treatment with Orset-x or Micoind, followed by soil addition of humic acid with Phosphrin or Orset-x. Whereas, the highest values of unmarketable fruit yield were obtained from the interaction treatment between soil addition of $100 \%$ mineral nitrogen (control treatment) and foliar spray with tap water, followed by the same soil addition treatment with Micoind or Orset-x or Phosphrin.
Obtained results were true during both seasons of growth.

\section{4- Chemical fruit quality}

Data recorded in Table (5) show clearly that there were asignificant differences in all assayed chemical constituents of the produced fruits among all tested soil addition treatments compared with the control treatment (100\% mineral nitrogen). Such data indicate that soil addition of $50 \%$ compost $+50 \%$ mineral nitrogen $+\mathrm{TS}$, reflected the highest constituents of TSS, VC, acidity, total sugars and anthocyanin compared with the other soil addition treatments followed by humic acid and EM, respectively. On the other hand, control treatment (100\%mineral nitrogen) recorded the lowest values for all chemical constituents of produced fruits. Obtained results are agreement with those reported by Hassan (2015), Reinaldo et al., (2015), Nazik et al. (2017) and Shubash et al., (2018)

With the regard to the effect of foliar spray with Phosphrin, Micoind and Orset-x, the same data presented in Table (5) show that foliar spraying treatments, , significantly increased all determined chemical fruit quality traits in produced fruit compared with the control treatment (foliar spray with tap water) during both seasons of study. In this respect, the highest values of chemical constituents content were obtained in case foliar spray with Phosphrin followed by Orset-x and Micoind, respectively, ten times during the growing seasons starting after 30 days from planting data and every 15 days as intervals between them. On the other hand, control treatment (foliar spray with tap water) recorded the lowest values. In this respect, this trend is true during the two seasons of study. Such increments in chemical fruit quality agents due to the effect of different studied growth stimulants are connected with the increase in photosynthetic pigments which in turn affect on the rate of organic compound assimilation and consequently increased such assayed organic constituents. Obtained results are in the same direction to those recorded by Spinelli et al. (2010), Alkharpotly et al.(2017), Husain et al. (2017), Ahire and Gaikwad (2018) and Scott et al. (2018)

Concerning the interaction effect between soil addition and foliar spray treatments, data in Table (5) revel that TSS, VC, total acidity, total sugars and anthocyanin content of the produced fruits were positively and significant affected due to the interaction treatment between soil addition and foliar spray treatments. In this regard, the highest chemical constituents content of produced fruits were reported due to the interaction between soil addition of $50 \%$ compost $+50 \%$ mineral nitrogen $+\mathrm{TS}$ and foliar spray with Phosphrin or Orset-x during the two seasons of study . 
Table 1. Effect of soil addition and foliar spray treatments as well as their interaction on vegetative growth characteristics of strawberry cv. Festival during the two seasons of study.

\section{Treatments}

\begin{tabular}{|c|c|c|c|c|c|c|c|c|c|c|c|c|c|c|c|}
\hline $\mathrm{N}$ - fertilization & $\begin{array}{l}\text { Foliar } \\
\text { spray }\end{array}$ & $\begin{array}{l}\text { Plant } \\
\text { height } \\
(\mathrm{cm}\end{array}$ & $\begin{array}{l}\text { Number } \\
\text { of } \\
\text { Leaves }\end{array}$ & $\begin{array}{l}\text { Number } \\
\text { of } \\
\text { crowns }\end{array}$ & $\begin{array}{l}\text { Crown } \\
\text { diameter }\end{array}$ & $\begin{array}{l}\text { Fresh } \\
\text { weight } \\
\text { (g) }\end{array}$ & $\begin{array}{l}\text { Dry } \\
\text { weight }(\mathrm{g})\end{array}$ & $\begin{array}{l}\text { Leaf } \\
\text { area } \\
\left(\mathrm{cm}^{2}\right)\end{array}$ & $\begin{array}{l}\text { Plant } \\
\text { height } \\
\text { (cm }\end{array}$ & $\begin{array}{l}\text { Number } \\
\text { of } \\
\text { Leaves }\end{array}$ & $\begin{array}{l}\text { Number } \\
\text { of } \\
\text { crowns }\end{array}$ & $\begin{array}{l}\text { Crown } \\
\text { diameter }\end{array}$ & $\begin{array}{l}\text { Fresh } \\
\text { weight } \\
\text { (g) }\end{array}$ & $\begin{array}{l}\text { Dry } \\
\text { weight }(\mathrm{g})\end{array}$ & $\begin{array}{l}\text { Leaf } \\
\text { area } \\
\left(\mathrm{cm}^{2}\right)\end{array}$ \\
\hline $50 \%$ compost $+50 \%$ mineral & & 20.1 & 16.6 & 2.84 & 2.96 & 59.3 & 11.89 & 392.9 & 19.2 & 15.7 & 2.54 & 2.58 & 56.4 & 11.31 & 381.1 \\
\hline $50 \%$ ompost $+50 \%$ minral & & 22.6 & 18.6 & 3.97 & 3.78 & 71.8 & 14.39 & 502.7 & 20.9 & 17.6 & 3.61 & 3.05 & 69.0 & 13.84 & 384.9 \\
\hline $50 \%$ ompost $+50 \%$ minral & & 21.1 & 17.1 & 3.29 & 3.43 & 64.8 & 12.98 & 440.4 & 20.1 & 16.4 & 2.87 & 2.69 & 62.2 & 12.46 & 430.7 \\
\hline Control (100\% mineral N) & & 18.6 & 14.9 & 2.19 & 2.47 & 49.4 & 9.92 & 320.5 & 17.0 & 14.1 & 2.10 & 2.04 & 47.1 & 9.45 & 310.3 \\
\hline \multirow[t]{5}{*}{ LSD at $5 \%$} & & 1.4 & 0.8 & 0.23 & 0.13 & 1.9 & 0.38 & 8.8 & 0.6 & 0.7 & 0.11 & 0.13 & 0.9 & 0.18 & 9.4 \\
\hline & Control & 19.3 & 11.8 & 2.60 & 2.86 & 53.3 & 10.69 & 348.9 & 17.3 & 11.1 & 2.31 & 2.28 & 50.1 & 10.03 & 337.8 \\
\hline & Phosphrin & 22.1 & 19.7 & 3.44 & 3.48 & 66.7 & 13.37 & 458.1 & 20.5 & 18.6 & 3.13 & 2.79 & 64.5 & 12.94 & 442.9 \\
\hline & Micoind & 20.02 & 17.0 & 3.02 & 3.13 & 61.4 & 12.33 & 413.6 & 19.3 & 16.3 & 2.77 & 2.60 & 58.8 & 11.77 & 404.8 \\
\hline & Orset-X & 21.1 & 18.6 & 3.24 & 3.34 & 63.9 & 12.80 & 435.7 & 20.1 & 17.7 & 2.91 & 2.69 & 61.4 & 12.31 & 421.4 \\
\hline LSD at 5\% & & 1.4 & 0.8 & 0.23 & 0.13 & 1.9 & 0.38 & 8.8 & 0.6 & 0.7 & 0.11 & 0.13 & 0.9 & 0.18 & 9.4 \\
\hline \multirow{4}{*}{$\begin{array}{l}\mathbf{5 0 \%} \text { compost }+50 \% \text { mineral } \\
\mathrm{N}+\mathrm{EM}\end{array}$} & Control & 18.6 & 11.4 & 2.63 & 2.65 & 54.1 & 10.87 & 349.6 & 17.7 & 10.7 & 2.36 & 2.34 & 50.3 & 10.11 & 341.3 \\
\hline & Phosphrin & 21.0 & 19.3 & 2.96 & 3.20 & 63.0 & 12.65 & 426.3 & 20.0 & 18.4 & 2.79 & 2.70 & 61.0 & 12.24 & 412.2 \\
\hline & Micoind & 20.3 & 17.0 & 2.83 & 2.93 & 58.8 & 11.78 & 387.4 & 19.3 & 16.1 & 2.52 & 2.62 & 55.7 & 11.16 & 378.7 \\
\hline & Orset-X & 20.6 & 18.7 & 2.93 & 3.06 & 61.1 & 12.26 & 408.0 & 19.6 & 17.7 & 2.48 & 2.66 & 58.6 & 11.72 & 391.6 \\
\hline \multirow{4}{*}{$\begin{array}{l}50 \% \text { compost }+50 \% \text { minral } \\
\mathrm{N}+\mathrm{TS}\end{array}$} & Control & 19.9 & 13.2 & 2.92 & 2.93 & 57.5 & 11.52 & 375.8 & 18.6 & 12.6 & 2.47 & 2.56 & 54.6 & 10.92 & 362.0 \\
\hline & Phosphrin & 25.3 & 22.2 & 4.62 & 4.30 & 80.6 & 16.13 & 582.5 & 22.4 & 20.9 & 4.33 & 3.38 & 77.2 & 15.51 & 557.2 \\
\hline & Micoind & 21.9 & 18.8 & 3.89 & 3.83 & 72.7 & 14.55 & 509.5 & 20.9 & 17.6 & 3.61 & 3.06 & 70.9 & 14.19 & 498.5 \\
\hline & Orset-X & 23.6 & 20.3 & 4.46 & 4.06 & 76.6 & 15.39 & 543.0 & 21.8 & 19.4 & 4.04 & 3.22 & 73.5 & 14.74 & 528.1 \\
\hline \multirow{4}{*}{$\begin{array}{l}50 \% \text { compost }+50 \% \text { mineral } \\
\mathrm{N}+\text { Humic acid }\end{array}$} & Control & 19.3 & 12.1 & 2.77 & 2.87 & 56.1 & 11.24 & 365.5 & 17.9 & 11.2 & 2.43 & 2.34 & 52.3 & 10.48 & 352.8 \\
\hline & Phosphrin & 22.4 & 20.0 & 3.78 & 3.83 & 77.7 & 14.15 & 484.2 & 21.4 & 19.2 & 3.20 & 2.87 & 68.4 & 13.69 & 473.9 \\
\hline & Micoind & 21.1 & 17.3 & 3.26 & 3.36 & 65.1 & 13.07 & 445.0 & 20.3 & 17.0 & 2.86 & 2.73 & 62.7 & 12.58 & 440.2 \\
\hline & Orset-X & 21.6 & 19.1 & 3.36 & 3.65 & 67.3 & 13.45 & 466.9 & 20.9 & 18.3 & 2.99 & 2.83 & 65.3 & 13.07 & 456.1 \\
\hline \multirow{4}{*}{ Control $(100 \%$ mineral $N)$} & Control & 19.3 & 10.7 & 2.06 & 2.27 & 45.4 & 9.12 & 304.8 & 15.1 & 9.8 & 1.99 & 1.90 & 43.1 & 8.62 & 295.1 \\
\hline & Phosphrin & 19.4 & 17.4 & 2.40 & 2.62 & 52.6 & 10.54 & 339.3 & 18.3 & 16.0 & 2.20 & 2.21 & 51.3 & 10.30 & 328.6 \\
\hline & Micoind & 17.2 & 14.9 & 2.10 & 2.39 & 49.1 & 9.91 & 312.7 & 16.8 & 14.7 & 2.08 & 2.0 & 45.7 & 9.16 & 301.7 \\
\hline & Orset-X & 18.3 & 16.6 & 2.22 & 2.58 & 50.6 & 10.13 & 325.0 & 18.0 & 15.5 & 2.14 & 2.06 & 48.4 & 9.70 & 315.8 \\
\hline LSD at $5 \%$ & & 2.8 & 1.7 & 0.47 & 0.26 & 3.8 & 0.77 & 17.6 & 1.2 & 1.4 & 0.23 & 0.27 & 1.9 & 0.37 & 18.9 \\
\hline
\end{tabular}


Table 2. Effect of soil addition and foliar spray treatments as well as their interaction on chemical constituents of plant foliage of strawberry cv. Festival during the two seasons of study.

\begin{tabular}{|c|c|c|c|c|c|c|c|c|c|}
\hline \multirow{2}{*}{$\begin{array}{l}\text { Treatments } \\
\text { N- fertilization }\end{array}$} & \multirow[b]{2}{*}{$\begin{array}{l}\text { Foliar } \\
\text { spray }\end{array}$} & \multicolumn{4}{|c|}{$2008 / 2009$} & \multicolumn{4}{|c|}{$2009 / 2010$} \\
\hline & & $\mathbf{N \%}$ & $\mathbf{P} \%$ & $\mathbf{K} \%$ & Total Carbohydrate \% & $\mathbf{N \%}$ & $\mathbf{P \%}$ & $\mathbf{K} \%$ & Total Carbohydrate\% \\
\hline $50 \%$ compost $+\mathbf{5 0} \%$ mineral $\mathrm{N}+\mathrm{EM}$ & & 2.45 & 0.41 & 2.02 & 8.69 & 2.29 & 0.35 & 1.86 & 7.42 \\
\hline $50 \%$ ompost $+50 \%$ minral N+ TS & & 2.70 & 0.46 & 2.16 & 9.14 & 2.56 & 0.42 & 2.04 & 8.25 \\
\hline $50 \%$ ompost $+50 \%$ minral N+ Humic acid & & 2.50 & 0.43 & 2.08 & 8.95 & 2.35 & 0.39 & 1.95 & 7.86 \\
\hline Control $(100 \%$ mineral $\mathrm{N})$ & & 2.27 & 0.37 & 1.91 & 7.03 & 2.16 & 0.30 & 1.69 & 6.28 \\
\hline \multirow[t]{5}{*}{ LSD at $5 \%$} & & 0.06 & 0.02 & 0.05 & 0.07 & 0.04 & 0.01 & 0.08 & 0.08 \\
\hline & Control & 2.38 & 0.35 & 1.90 & 7.99 & 2.25 & 0.31 & 1.77 & 6.97 \\
\hline & Phosphrin & 2.59 & 0.47 & 2.20 & 8.84 & 2.43 & 0.41 & 2.0 & 8.08 \\
\hline & Micoind & 2.42 & 0.41 & 2.01 & 8.40 & 2.32 & 0.35 & 1.86 & 7.25 \\
\hline & Orset-X & 2.52 & 0.44 & 2.07 & 8.58 & 2.35 & 0.38 & 1.91 & 7.50 \\
\hline LSD at $5 \%$ & & 0.06 & 0.02 & 0.05 & 0.07 & 0.04 & 0.01 & 0.08 & 0.08 \\
\hline \multirow{4}{*}{$50 \%$ compost $+\mathbf{5 0} \%$ mineral $\mathrm{N}+\mathrm{EM}$} & Control & 2.40 & 0.34 & 1.91 & 8.21 & 2.23 & 0.30 & 1.73 & 7.03 \\
\hline & Phosphrin & 2.57 & 0.47 & 2.15 & 9.04 & 2.41 & 0.39 & 1.99 & 7.95 \\
\hline & Micoind & 2.36 & 0.40 & 2.01 & 8.66 & 2.29 & 0.34 & 1.84 & 7.14 \\
\hline & Orset-X & 2.48 & 0.44 & 2.04 & 8.88 & 2.26 & 0.37 & 1.88 & 7.56 \\
\hline \multirow{4}{*}{$50 \%$ compost $+50 \%$ minral $N+T S$} & Control & 2.54 & 0.41 & 2.02 & 8.93 & 2.48 & 0.37 & 1.96 & 7.85 \\
\hline & Phosphrin & 2.85 & 0.52 & 2.35 & 9.43 & 2.66 & 0.48 & 2.13 & 8.75 \\
\hline & Micoind & 2.68 & 0.46 & 2.11 & 9.07 & 2.51 & 0.40 & 2.02 & 8.12 \\
\hline & Orset-X & 2.76 & 0.48 & 2.17 & 9.16 & 2.59 & 0.43 & 2.08 & 8.28 \\
\hline \multirow{4}{*}{$50 \%$ compost $+50 \%$ mineral $\mathrm{N}+$ Humic acid } & Control & 2.41 & 0.37 & 1.96 & 8.64 & 2.26 & 0.35 & 1.88 & 7.19 \\
\hline & Phosphrin & 2.61 & 0.50 & 2.26 & 9.16 & 2.43 & 0.44 & 2.07 & 8.42 \\
\hline & Micoind & 2.43 & 0.43 & 2.03 & 8.95 & 2.33 & 0.38 & 1.92 & 7.74 \\
\hline & Orset-X & 2.55 & 0.45 & 2.10 & 9.03 & 2.38 & 0.41 & 1.96 & 8.09 \\
\hline \multirow{4}{*}{ Control (100\% mineral N) } & Control & 2.18 & 0.30 & 1.73 & 6.21 & 2.05 & 0.25 & 1.52 & 5.83 \\
\hline & Phosphrin & 2.36 & 0.42 & 2.04 & 7.75 & 2.24 & 0.35 & 1.82 & 7.21 \\
\hline & Micoind & 2.24 & 0.37 & 1.92 & 6.93 & 2.17 & 0.31 & 1.68 & 6.01 \\
\hline & Orset-X & 2.30 & 0.39 & 1.98 & 7.25 & 2.19 & 0.32 & 1.75 & 6.09 \\
\hline LSD at $5 \%$ & & 0.13 & 0.05 & 0.11 & 0.15 & 0.09 & 0.3 & 0.19 & 0.19 \\
\hline
\end{tabular}


Table 3. Effect of soil addition and foliar spray treatments as well as their interaction on fruit yield and its component of strawberry cv. Festival during the two seasons of study.

\begin{tabular}{|c|c|c|c|c|c|c|c|c|c|c|c|c|c|}
\hline \multicolumn{14}{|l|}{ Treatments } \\
\hline $\mathrm{N}$ - fertilization & Foliar & Early & Exportab & Total & Tota & Marketabl & Unmarketabl & Early & Exporta & Total & Tota & Marketabl & Unmarketabl \\
\hline $50 \%$ compost $+50 \%$ mineral & & 6.99 & 4.35 & 468.7 & 20.6 & 19.56 & 1060 & 6.76 & 4.20 & 450.6 & 19.7 & 19.09 & 700 \\
\hline $50 \%$ ompost $+50 \%$ minral $\mathrm{N}+$ & & 7.59 & 4.73 & 531.5 & 23.4 & 22.18 & 1240 & 7.44 & 4.58 & 513.1 & 22.5 & 21.49 & 1080 \\
\hline $50 \%$ ompost $+50 \%$ minral $\mathrm{N}+$ & & 7.31 & 4.60 & 501.8 & 22.0 & 20.60 & 1480 & 7.01 & 4.30 & 477.6 & 21.0 & 19.77 & 1250 \\
\hline Control $(100 \%$ mineral $N)$ & & 6.46 & 4.01 & 400.1 & 18.3 & 16.68 & 1630 & 6.28 & 4.13 & 401.2 & 17.7 & 16.32 & 1430 \\
\hline \multirow[t]{5}{*}{ LSD at $5 \%$} & & 0.17 & 0.08 & 25.6 & 0.39 & 0.52 & 19 & 0.08 & 0.06 & 8.1 & 0.33 & 0.31 & 17 \\
\hline & Control & 6.29 & 3.53 & 418.5 & 19.1 & 17.76 & 1420 & 6.22 & 3.54 & 422.1 & 18.5 & 17.32 & 1210 \\
\hline & Phosphri & 7.47 & 4.83 & 510.2 & 22.4 & 20.99 & 1460 & 7.15 & 4.59 & 484.1 & 21.4 & 20.37 & 1030 \\
\hline & Micoind & 6.99 & 4.47 & 478.4 & 21.0 & 19.74 & 1290 & 6.77 & 4.37 & 462.0 & 20.3 & 19.19 & 1150 \\
\hline & Orset-X & 7.59 & 4.86 & 495.0 & 21.7 & 20.52 & 1260 & 7.36 & 4.72 & 474.4 & 20.8 & 19.79 & 1080 \\
\hline LSD at $5 \%$ & & 0.17 & 0.08 & 25.6 & 0.39 & 0.52 & 19 & 0.08 & 0.07 & 8.1 & 0.33 & 0.31 & 18 \\
\hline \multirow{4}{*}{$\begin{array}{l}\mathbf{5 0 \%} \text { compost }+50 \% \text { mineral } \\
\text { N+ EM }\end{array}$} & Control & 6.23 & 3.48 & 436.6 & 19.2 & 18.29 & 926 & 6.18 & 3.45 & 425.9 & 18.5 & 17.80 & 784 \\
\hline & Phosphri & 7.42 & 4.75 & 496.7 & 21.8 & 20.11 & 737 & 6.99 & 4.47 & 467.9 & 20.5 & 19.97 & 616 \\
\hline & Micoind & 6.80 & 4.35 & 461.9 & 20.3 & 19.49 & 830 & 6.68 & 4.27 & 449.1 & 19.9 & 19.02 & 733 \\
\hline & Orset-X & 7.52 & 4.81 & 479.8 & 21.1 & 20.33 & 780 & 7.17 & 4.59 & 459.8 & 20.2 & 19.56 & 673 \\
\hline \multirow{4}{*}{$\begin{array}{l}50 \% \text { compost }+50 \% \text { minral } \mathrm{N}+ \\
\text { TS }\end{array}$} & Control & 6.46 & 3.63 & 449.9 & 19.9 & 18.49 & 1300 & 6.41 & 3.60 & 439.6 & 19.3 & 18.14 & 1131 \\
\hline & Phosphri & 8.08 & 5.16 & 577.3 & 25.4 & 24.30 & 1105 & 7.79 & 4.99 & 554.5 & 24.4 & 23.40 & 995 \\
\hline & Micoind & 7.62 & 4.87 & 542.1 & 23.8 & 22.60 & 1249 & 7.32 & 4.68 & 520.9 & 22.9 & 21.83 & 1090 \\
\hline & Orset-X & 8.19 & 5.24 & 557.0 & 24.5 & 23.34 & 1163 & 8.24 & 5.06 & 537.5 & 23.6 & 22.60 & 1050 \\
\hline \multirow{4}{*}{$\begin{array}{l}50 \% \text { compost }+50 \% \text { mineral } \\
\text { N+ Humic acid }\end{array}$} & Control & 6.37 & 3.57 & 450.4 & 19.8 & 18.26 & 1551 & 6.28 & 3.52 & 432.8 & 19.0 & 17.74 & 1267 \\
\hline & Phosphri & 7.78 & 5.17 & 536.6 & 23.6 & 22.20 & 1415 & 7.38 & 4.55 & 507.2 & 22.3 & 21.13 & 1191 \\
\hline & Micoind & 7.23 & 4.63 & 498.9 & 21.9 & 20.46 & 1495 & 6.94 & 4.36 & 478.5 & 21.0 & 19.77 & 1271 \\
\hline & Orset-X & 7.87 & 5.03 & 521.3 & 22.9 & 21.48 & 1460 & 7.46 & 4.77 & 492.2 & 21.6 & 20.43 & 1220 \\
\hline \multirow{4}{*}{ Control $(100 \%$ mineral $N)$} & Control & 6.11 & 3.41 & 337.1 & 17.7 & 15.99 & 1768 & 6.01 & 3.58 & 390.3 & 17.1 & 15.61 & 1560 \\
\hline & Phosphri & 6.62 & 4.23 & 430.2 & 18.9 & 17.33 & 1593 & 6.43 & 4.35 & 406.9 & 18.3 & 16.97 & 1333 \\
\hline & Micoind & 6.32 & 4.04 & 410.8 & 17.9 & 16.43 & 1656 & 6.15 & 4.17 & 399.5 & 17.5 & 16.13 & 1453 \\
\hline & Orset-X & 6.77 & 4.33 & 422.1 & 18.5 & 16.95 & 1616 & 6.55 & 4.44 & 408.2 & 17.9 & 16.56 & 1391 \\
\hline LSD at $5 \%$ & & 0.34 & 0.16 & 51.3 & 0.78 & 1.05 & 39 & 0.19 & 0.13 & 16.3 & 0.65 & 0.62 & 36 \\
\hline
\end{tabular}


Table 4. Effect of soil addition and foliar spray treatments as well as their interaction on physical fruit quality of strawberry cv. Festival during the two seasons of study.

\begin{tabular}{|c|c|c|c|c|c|c|c|c|c|}
\hline \multicolumn{2}{|l|}{ Treatments } & \multicolumn{4}{|l|}{$2008 / 2009$} & \multicolumn{4}{|l|}{$2009 / 2010$} \\
\hline $\mathrm{N}$ - fertilization & $\begin{array}{l}\text { Foliar } \\
\text { spray }\end{array}$ & $\begin{array}{l}\text { Fruit } \\
\text { weight(g) }\end{array}$ & $\begin{array}{l}\text { Fruit } \\
\text { length }(\mathrm{cm})\end{array}$ & $\begin{array}{l}\text { Fruit } \\
\text { diameter(cm) }\end{array}$ & $\begin{array}{l}\text { Fruit } \\
\text { firmness }(\mathrm{g} / \mathrm{cm} 2)\end{array}$ & $\begin{array}{l}\text { Fruit } \\
\text { weight(g) }\end{array}$ & $\begin{array}{l}\text { Fruit } \\
\text { length }(\mathrm{cm})\end{array}$ & $\begin{array}{l}\text { Fruit } \\
\text { diameter(cm) }\end{array}$ & $\begin{array}{l}\text { Fruit } \\
\text { firmness }(\mathrm{g} / \mathrm{cm} 2)\end{array}$ \\
\hline $50 \%$ compost $+50 \%$ mineral & & 19.3 & 4.03 & 3.40 & 240 & 18.1 & 4.58 & 3.06 & 238 \\
\hline $50 \%$ ompost $+50 \%$ minral & & 23.9 & 4.73 & 3.65 & 261 & 22.5 & 5.23 & 3.44 & 252 \\
\hline $50 \%$ ompost $+50 \%$ minral & & 21.5 & 4.41 & 3.53 & 256 & 20.6 & 4.86 & 3.23 & 244 \\
\hline Control (100\% mineral N) & & 12.5 & 3.20 & 2.83 & 225 & 12.9 & 3.46 & 2.57 & 219 \\
\hline \multirow[t]{5}{*}{ LSD at $5 \%$} & & 0.94 & 0.17 & 0.09 & 4.9 & 1.2 & 0.08 & 0.06 & 5.6 \\
\hline & Control & 15.4 & 3.52 & 3.10 & 235 & 14.8 & 3.98 & 2.97 & 229 \\
\hline & Phosphrin & 21.6 & 4.27 & 3.55 & 259 & 21.1 & 4.72 & 3.25 & 249 \\
\hline & Micoind & 19.3 & 4.10 & 3.31 & 242 & 18.8 & 4.52 & 3.09 & 234 \\
\hline & Orset-X & 20.8 & 4.48 & 3.45 & 247 & 19.5 & 4.91 & 3.18 & 240 \\
\hline \multicolumn{2}{|l|}{ LSD at $5 \%$} & 0.94 & 0.17 & 0.09 & 4.9 & 1.2 & 0.08 & 0.06 & 5.6 \\
\hline \multirow{4}{*}{$\begin{array}{l}\mathbf{5 0 \%} \text { compost }+50 \% \text { mineral } \\
\mathrm{N}+\mathrm{EM}\end{array}$} & Control & 15.3 & 3.63 & 3.23 & 231 & 14.2 & 4.23 & 2.83 & 231 \\
\hline & Phosphrin & 21.9 & 4.10 & 3.46 & 255 & 20.6 & 4.66 & 3.16 & 249 \\
\hline & Micoind & 19.1 & 4.0 & 3.43 & 238 & 18.5 & 4.60 & 3.10 & 234 \\
\hline & Orset-X & 20.8 & 4.40 & 3.50 & 238 & 19.3 & 4.83 & 3.16 & 241 \\
\hline \multirow{4}{*}{$\begin{array}{l}50 \% \text { compost }+50 \% \text { minral } \\
\mathrm{N}+\mathrm{TS}\end{array}$} & Control & 18.2 & 3.83 & 3.43 & 249 & 14.4 & 4.50 & 3.03 & 241 \\
\hline & Phosphrin & 26.6 & 5.06 & 3.86 & 267 & 25.2 & 5.43 & 3.70 & 264 \\
\hline & Micoind & 24.7 & 4.80 & 3.60 & 258 & 23.6 & 5.33 & 3.46 & 247 \\
\hline & Orset-X & 26.0 & 5.23 & 3.70 & 264 & 24.0 & 5.66 & 3.56 & 256 \\
\hline \multirow{4}{*}{$\begin{array}{l}\mathbf{5 0 \%} \text { compost }+\mathbf{5 0} \% \text { mineral } \\
\mathrm{N}+\text { Humic acid }\end{array}$} & Control & 17.1 & 3.96 & 3.33 & 244 & 15.5 & 4.36 & 2.93 & 238 \\
\hline & Phosphrin & 23.8 & 4.53 & 3.70 & 269 & 23.3 & 5.03 & 3.40 & 254 \\
\hline & Micoind & 22.1 & 5.50 & 3.50 & 252 & 21.7 & 4.86 & 3.26 & 240 \\
\hline & Orset-X & 23.2 & 4.66 & 3.60 & 259 & 22.0 & 5.20 & 3.33 & 245 \\
\hline \multirow{4}{*}{ Control (100\% mineral N) } & Control & 11.2 & 2.66 & 2.40 & 216 & 10.6 & 2.83 & 2.36 & 207 \\
\hline & Phosphrin & 14.3 & 3.40 & 3.20 & 237 & 17.2 & 3.76 & 2.73 & 232 \\
\hline & Micoind & 11.5 & 3.10 & 3.73 & 222 & 11.4 & 3.30 & 2.53 & 218 \\
\hline & Orset-X & 13.1 & 3.63 & 3.0 & 228 & 12.5 & 3.96 & 2.66 & 221 \\
\hline LSD at $5 \%$ & & 1.89 & 0.35 & 0.18 & 9.9 & 2.6 & 0.16 & 0.12 & 11.3 \\
\hline
\end{tabular}


Table 5. Effect of soil addition and foliar spray treatments as well as their interaction on chemical fruit quality of strawberry cv. Festival during the two seasons of study.

\begin{tabular}{|c|c|c|c|c|c|c|c|c|c|c|c|c|}
\hline \multirow{2}{*}{\begin{tabular}{l|} 
Treatments \\
N- fertilization \\
\end{tabular}} & \multicolumn{4}{|c|}{$2008 / 2009$} & \multirow[b]{2}{*}{ Total } & \multirow{2}{*}{ Anthocyanin } & \multirow{2}{*}{ T.S.S \% } & \multicolumn{5}{|c|}{$2009 / 2010$} \\
\hline & Foliar spray & T. S. S \% & $\mathrm{V}$. & C $\quad$ Acidity & & & & $\mathrm{V}$. & $\mathrm{C}$ & Acidity & Total & Anthocyanin \\
\hline $50 \%$ compost $+50 \%$ mineral & & 10.9 & 50.33 & 0.68 & 7.21 & 86.2 & 10.3 & 53.36 & & 0.73 & 6.96 & 74.8 \\
\hline $50 \%$ ompost $+50 \%$ minral & & 11.3 & 55.78 & 0.80 & 7.55 & 92.6 & 10.5 & 58.14 & & 0.84 & 7.30 & 87.1 \\
\hline $\mathbf{5 0} \%$ ompost $+\mathbf{5 0} \%$ minral & & 11.1 & 52.99 & 0.75 & 7.33 & 89.5 & 10.4 & 55.46 & & 0.79 & 7.11 & 78.8 \\
\hline Control $(100 \%$ mineral $N)$ & & 10.3 & 42.47 & 0.54 & 6.98 & 84.1 & 9.4 & 44.82 & & 0.61 & 6.76 & 68.8 \\
\hline LSD at $5 \%$ & & 0.10 & 0.91 & 0.02 & 0.06 & 3.42 & 0.32 & 0.83 & & 0.01 & 0.05 & 1.48 \\
\hline \multirow{9}{*}{$\begin{array}{l}\text { LSD at } 5 \% \\
50 \% \text { compost }+50 \% \text { mineral } \\
\text { N+ EM }\end{array}$} & Control & 10.6 & 46.13 & 0.60 & 7.05 & 82.5 & 9.7 & 48.63 & & 0.66 & 6.91 & 74.5 \\
\hline & Phosphrin & 11.1 & 53.07 & 0.75 & 7.47 & 91.7 & 10.4 & 55.70 & & 0.79 & 7.19 & 80.0 \\
\hline & Micoind & 11.0 & 50.68 & 0.70 & 7.22 & 88.1 & 10.2 & 52.94 & & 0.75 & 6.99 & 76.8 \\
\hline & Orset-X & 11.0 & 51.68 & 0.72 & 7.32 & 90.2 & 10.3 & 54.53 & & 0.77 & 7.04 & 78.1 \\
\hline & & 0.11 & 0.91 & 0.02 & 0.05 & 3.42 & 0.30 & 0.83 & & 0.02 & 0.05 & 1.48 \\
\hline & Control & 10.6 & 46.61 & 0.60 & 7.06 & 75.3 & 10.0 & 49.30 & & 0.67 & 6.83 & 71.6 \\
\hline & Phosphrin & 11.1 & 53.04 & 0.73 & 7.39 & 91.2 & 10.4 & 56.21 & & 0.77 & 7.09 & 77.6 \\
\hline & Micoind & 11.0 & 50.44 & 0.69 & 7.17 & 88.6 & 10.3 & 53.10 & & 0.72 & 6.96 & 74.9 \\
\hline & Orset-X & 10.9 & 51.24 & 0.69 & 7.24 & 89.8 & 10.3 & 54.85 & & 0.75 & 6.98 & 75.4 \\
\hline \multirow{4}{*}{$\begin{array}{l}\mathbf{5 0 \%} \text { compost }+50 \% \text { minral } \\
\text { N+ TS }\end{array}$} & Control & 10.9 & 49.56 & 0.66 & 7.21 & 87.4 & 10.3 & 52.59 & & 0.72 & 7.16 & 84.5 \\
\hline & Phosphrin & 11.5 & 58.60 & 0.87 & 7.83 & 97.2 & 10.7 & 60.69 & & 0.90 & 7.55 & 89.7 \\
\hline & Micoind & 11.5 & 57.18 & 0.83 & 7.52 & 91.5 & 10.6 & 59.01 & & 0.86 & 7.20 & 86.4 \\
\hline & Orset-X & 11.4 & 57.77 & 0.85 & 7.64 & 94.3 & 10.7 & 60.25 & & 0.88 & 7.29 & 87.5 \\
\hline \multirow{4}{*}{$\begin{array}{l}50 \% \text { compost }+50 \% \text { mineral } \\
\mathrm{N}+\text { Humic acid }\end{array}$} & Control & 10.8 & 48.58 & 0.63 & 7.15 & 85.7 & 10.2 & 51.29 & & 0.69 & 7.01 & 76.9 \\
\hline & Phosphrin & 11.3 & 55.76 & 0.80 & 7.54 & 90.8 & 10.6 & 57.69 & & 0.85 & 7.28 & 81.7 \\
\hline & Micoind & 11.2 & 53.19 & 0.76 & 7.28 & 90.2 & 10.5 & 55.92 & & 0.80 & 7.06 & 77.6 \\
\hline & Orset-X & 11.3 & 54.42 & 0.79 & 7.36 & 91.6 & 10.5 & 56.95 & & 0.82 & 6.11 & 79.2 \\
\hline \multirow[t]{4}{*}{ Control (100\% mineral $N)$} & Control & 10.0 & 39.78 & 0.49 & 6.81 & 81.6 & 8.2 & 41.32 & & 0.57 & 6.64 & 65.3 \\
\hline & Phosphrin & 10.6 & 44.90 & 0.58 & 7.14 & 87.6 & 10.0 & 48.22 & & 0.66 & 6.87 & 71.2 \\
\hline & Micoind & 10.3 & 41.93 & 0.53 & 6.92 & 82.1 & 9.6 & 43.71 & & 0.61 & 6.75 & 68.5 \\
\hline & Orset-X & 10.5 & 43.29 & 0.55 & 7.07 & 85.3 & 9.7 & 46.06 & & 0.62 & 6.81 & 70.4 \\
\hline LSD at $5 \%$ & & 0.22 & 1.82 & 0.05 & 0.13 & 6.85 & 0.64 & 1.66 & & 0.04 & 0.10 & 2.96 \\
\hline
\end{tabular}




\section{References}

A. O.A. C. 1990. Official and tentative methods of analysis. Association of Official Analytical Chemists. Washington, D.C,U.S.A.

Abu-Zahra, T.R. and A.A. Tahboub,( 2008). Strawberry (Fragaria x Anansa Dutch ) growth, flowering and yielding as affected by different organic matter sources. Intern .J. of Botany, 4 (4):481-485.

Alkharpotly, A. A.1; R. A. Mohamed; M. N. Shehata1 and A. A. M. Awad (2017). Impact of soil humic acid soil application and seaweed extract foliar spray on growth, yield and fruits quality of strawberry plants grown under Aswan conditions. J. Soil Sci. and Agric. Eng., Mansoura Univ.,8(6):307 - 315.

Brown, J. and O. Lilliland. 1946. Rapid determination of potassium and sodium in plant material and soil extracts by flame photometric. Proc. Amer. Soc. Hort. Sci., 48: 341 - 346

Dhargalkar, V. and Pereira, K. (2005). Seaweed: promising plant of the millennium, Sci. Cult.,71: 60-66

El-Hefny, E. M. (2010). Effect of saline irrigation water and humic acid application on growth and productivity of two cultivars of Cowpea (Vigna unguiculata L. Walp). Aust. J. Basic Appl. Sci., 4: 6154-6168.

Hargreaves, J.C., M.S. Adl and P.R. Warman, (2009). Are compost teas an Effective nutrient amendment in the cultivation of strawberries? Soil and plant tissue effects .J. Sci. Food .Agric. 89: 390-397.

Hassan. A. H. (2015). Effect of nitrogen fertilizer levels in the form of organic, inorganic and bio fertilizer applications on growth, yield and quality of strawberry. Mid. East J. App. Sci., 5(2): 604617

Herbert, D.; P.J. Phipps and R.E. Strange. 1971. Determination of total carbohydrates, Methods in Microbiology, 5 (8): 290-344.

Husain A., M. Sajjid, S.Hayat, R. Ullah, M. Ali, A. Jamal, A. Rahman, Z. Aman an J. Ali .2017. Growth, yield and fruit quality of strawberry (Frageria ananasa Duch) under different Phosphorus Levels, Res. Agric.,2(2): 2740-2748.

Javaid, A., and M.B.M. Shah, (2010). Growth and yield response of wheat to EM (Effective microorganisms) and parthenium green manure. African Journal of Biotechnology 9:3378-3381.

John, M. K. 1970. Colorimetric determination of phosphorus in soil and plant material with ascorbic acid. Soil Sci.,109:214-220.

Kumar, R., Sharma, N., Jamwal, M., Sharma, R. M., Singh, D. B., and Parmar, A. M. (2012). Production and economic studies of PBRs treated strawberry (Frageria x ananassa Duch.) cv. Sweet
Charlie. American-Eurasian Journal of Agriculture and Environmental Science, 12(12), 1.

Li, H.; Huang, R.; Li, T.; Hu, K. (2010). Ability of nitrogen and phosphorus assimilation of seven strawberry cultivars in a northern Atlantic coastal soil. In: World Congress of Soil Science, Soil Solutions for a Changing World, 19, 2010, Brisbane. Anais...Brisbane: EPSO.

Masny A., A. Basak and E. śurawicz (2004). Effects of foliar applications of Kelpak Sl and GoëmarBm Preparations on yield and fruit quality in two Strawberry cultivars. J. Fruit \& Ornam. Pl. Res., 12: 23-27.

Nazik, M., H. Khalil and R. J. Agah (2017). Effect of Chemical, Organic and Bio Fertilization on Growth and Yield of Strawberry Plant. nt'l Journal of Advances in Chemical Engg., \& Biological Sciences, 4(1):215-222.

Nelson, N. 1974. A photometric adaptation of the somogyi methods for determination of glucose. J. Biology. Chem. 195: 19-23.

Pregl, E. 1945. Quantitative organic micro analysis. $4^{\text {th }}$ Ed. J. Chundril, London.

Qurecky, D.K., and M.C. Bourne. 1968. Measurement of strawberry texture. J. Amer. Sci., 93:317-339

Reinaldo F. Medeiros , Walter E. Pereira , Rummenigge de M. Rodrigues, Ronaldo do Nascimento, Janivan F. Suassuna \& Tony A. G. Dantas (2015). Growth and yield of strawberry plants fertilized with nitrogen and phosphorus. Revista Brasileira de Engenharia Agrícola e Ambiental Campina Grande, 19(9):865-870.

Saurabh K. Singh, Ashvin A. Bhople, Paresh P. Kullarkar*, Nikhil Bhople and Ajay Jumale (2018). Plant Growth Regulators and Strawberry Production., Int.J.Curr.Microbiol.App.Sci ,7(8): 2413-2419.

Scott, W. Mattner, Mirko Milinkovic and Tony Arioli (2018). Increased growth response of strawberry roots to a commercial extract from Durvillaea potatorum and Ascophyllum nodosum. J. Appl. Phycol.,30(5):2943-2951.

Sharma, R.R., (2002). Growing Strawberry. International Book Distributing Co. Indian, p. 164.

Snedecor, G. W. and W.G. Cocharn. 1991. Statistical methods. $8^{\text {th }}$ E.d., lowa State Univ. press, Lowa. USA

Spinelli, F., F. Giovanni, N. Massimo, S. Mattia and G. Costa. 2010. Anovel type of seaweed extract as a natural alternative to the use of iron chelates in strawberry production. Scientia Horticulture. 125:263-269.

Venkatashwarlu, B., (2008). Role of bio-fertilizers in organic farming: Organic farming in rain fed agriculture: Central institute for dry land agriculture, Hyderabad, 85-95. 


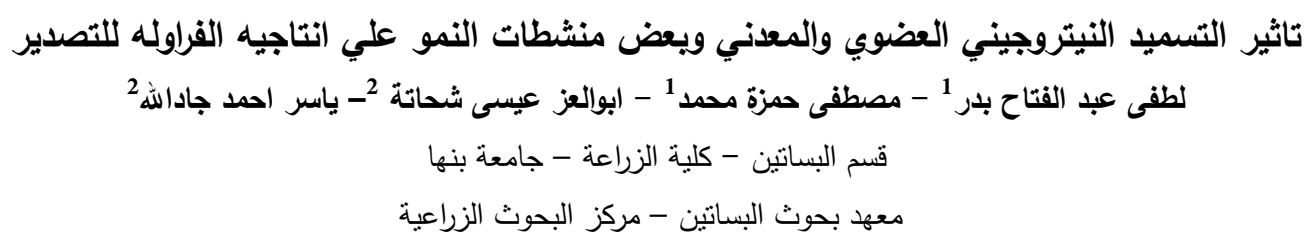

أجريت تجربتان حقليتان خلال موسمي الزراعه لعامى 2018/2017 و 2019/2018 في محطه بحوث القناطر الخيريه بمحافظه القليوبيه لدراسه تاثثر التسميد النيتروجيني العضوي والمعدني والاضافه الارضيه لكلأ من حمض الهيوميك والكائنات الحيه الدقيقه النافعه (EM) وكذلك الرش ببعض منشطات النمو (الفسفورين - الميكودين - اورست) علي صفات النمو الخضري والتركيب الكيماوي والمحصول الثمرية و مكاوناته وصفات الجوده لنباتات الفراوله صنف فرنونا. وقد اثنلمت التجربه على 16 معامله ناتجه من التفاعل بين اربع مستويات من التسميد النيتروجيني

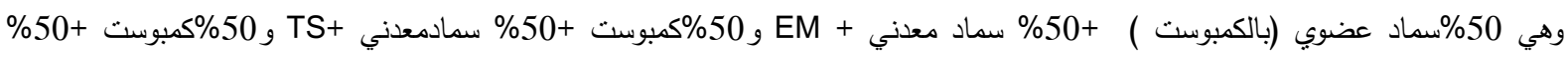
سمادمعدني + حمض الهيومك و 100\%سماد نيتروجيني معدني بالمعدل الموصي به (200كجم نيتروجين للفدان )كمعامله المقارنه وكذلك الرش وفئ

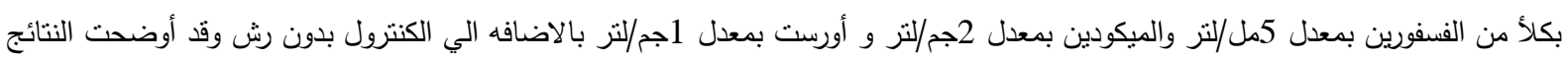

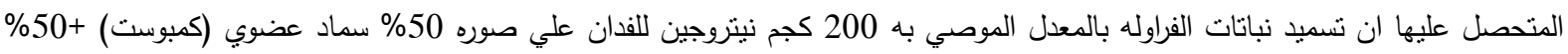
سماد معدني والاضافه الارضيه TS والرش بمركب الفسفورين بمعدل 5مل/لتر اعطي اعلي النتائج لكلأ من صفات النمو الخضري والنركيب باتي باتي الكيماوي للمجموع الخضري والمحصول الثمري ومكوناته (المبكر - التصديري - القابل للتسويق -محصول النبات وكذلك محصول الفدان) وكذلك اعلكي

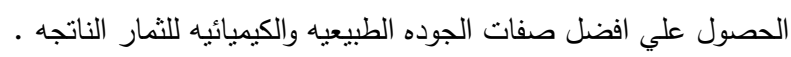

